\title{
Calciphylaxis: Current Management and Emerging Therapies
}

\author{
Eleftheriadis $\mathrm{T}^{1}$, Leivaditis $\mathrm{K}^{2}$, Antoniadi $\mathrm{G}^{2}$ and Liakopoulos $\mathrm{V}^{2 *}$
}

${ }^{1}$ Department of Nephrology, Medical School, University of Thessaly, University Hospital of Larissa, Larissa, Greece

${ }^{2}$ Division of Nephrology, $1^{\text {st }}$ Department of Internal Medicine, Medical School, Aristotle University of Thessaloniki, AHEPA Hospital, Thessaloniki, Greece

\begin{abstract}
Calciphylaxis or calcific uremic arteriolopathy is a relatively uncommon condition with poor prognosis. Although it is predominantly observed in patients with end stage renal disease, a few cases of patients without kidney failure have been reported. Calciphylaxis is characterized by calcification of the arteriolar intima media and eventually by vascular thrombosis, tissue ischemia and painful skin necrosis. Septicemia is the main cause of death. According to published literature concerning the pathology of calciphylaxis, prevention and treatment are principally based on interventions in calcium and phosphorus metabolism. Although novel therapies have emerged, due to the rarity of this condition, there is no sufficient data in favor of a certain treatment.
\end{abstract}

Keywords: Calciphylaxis; Sodium thiosulphate; Bisphosphonates; Treatment

\section{Introduction}

Calciphylaxis or calcific uremic arteriolopathy is a syndrome of vascular calcification, thrombosis and skin necrosis. It is seen almost exclusively in patients with end stage kidney disease. It is a type of extraosseous calcification. The exact pathogenetic mechanisms are not well understood and possible factors involved in its pathogenesis are mentioned below. The disease does not only affect patients with kidney failure. Although relatively rare, calciphylaxis results in chronic nonhealing wounds and is usually fatal.

\section{Pathogenesis of Calciphylaxis}

The main pathologic feature of calciphylaxis, calcification of skin arterioles, has guided research towards factors involved in calcium (Ca) and phosphorus $(\mathrm{P})$ balance.

\section{Factors that Promote Calcification}

\section{Parathyroid hormone (PTH)}

There are cases of calciphylaxis that have been successfully managed by parathyroidectomy [1-3]. However, not all patients with hyperparathyroidism develop calciphylaxis. Although calciphylaxis is more frequent in the latter, there are also reports of patients with normal, low or undetectable serum PTH that have undergone parathyroidectomy in the past $[2,4,5]$. On the other hand, there are case reports of calciphylaxis in patients with uncontrolled primary hyperpararthyroidism and normal renal function. It is possible that parathyroidectomy may prove beneficial by normalizing $\mathrm{Ca}$ and $\mathrm{P}$ homeostasis and by rapid declining of the Ca x P product during the postoperative period.

\section{Vitamin D and calcium based phosphate binders}

Active vitamin $\mathrm{D}$ or vitamin $\mathrm{D}$ analogues administration, as well as calcium containing phosphate binders prescribed for the treatment of secondary hyperparathyroidism are potentially involved in the pathogenesis of calciphylaxis by increasing Ca x P product [6-9].

\section{Hypercalcemia and hyperphosphatemia}

These disorders seem to be the main factors responsible for arteriolar calcification and the development of calciphylaxis [10-11]. Disturbances in the homeostasis of $\mathrm{Ca}, \mathrm{P}$ and $\mathrm{PTH}$ may depict the initial sensitization part of a two-hit model, where some other stimulus (systemic or local) is needed in order to initiate the combined process of inflammation and calcification leading to calciphylaxis. On the other hand, Ca deposits may reflect a secondary event, an epiphenomenon following a not yet elucidated triggering primary event. In any case rigorous control of $\mathrm{Ca}, \mathrm{P}$ and $\mathrm{PTH}$ levels is necessary since they have been recognized as precipitating factors in the course of calciphylaxis. $[12,13]$

\section{Factors that Inhibit Calcification}

\section{Matrix-Gla protein (MGP)}

MGP is a glycoprotein produced by vascular smooth muscle cells and chondrocytes and it is a local calcification inhibitor. In MGP knockout mice, massive median calcification takes place and death ensues after 6 weeks approximately due to rupture of the aorta [1415]. MGP activation requires its carboxylation which is vitamin $K$ dependent [16-17]. This fact can partially explain the observation that administration of vitamin $\mathrm{K}$ inhibitors like warfarin may be associated with calciphylaxis $[4,18]$.

\section{Fetuin-A}

In contrast to MGP which acts locally, fetuin-A is a systemic calcification inhibitor. This glycoprotein is produced in the liver and is found in serum in high concentrations $(0.5-1 \mathrm{~g} / \mathrm{L})$ [19]. Fetuin-A knockout mice develop significant calcifications [20]. Interestingly, fetuin-A levels are reduced in inflammation [19,21]. In the few cases of calciphylaxis in patients without chronic kidney failure, an inflammatory disease was present, like connective tissue disease or Crohn's disease $[22,23]$. Chronic kidney disease is also an inflammatory state [24] and in the majority of patients undergoing hemodialysis,

*Corresponding author: Vassilios Liakopoulos, Assistant Professor of Nephrology, Division of Nephrology, $1^{\text {st }}$ Department of Internal Medicine, Medical School, Aristotle University of Thessaloniki, AHEPA Hospital, $1 \mathrm{~S}$. Kyriakidi street, 54634, Thessaloniki, Greece, Tel: +302310994694; Fax: +302310994694; E-mail liakopul@otenet.gr

Received November 15, 2011; Accepted January 04, 2012; Published January 06, 2012

Citation: Eleftheriadis T, Leivaditis K, Antoniadi G, Liakopoulos V (2012) Calciphylaxis: Current Management and Emerging Therapies. J Nephrol Therapeutic S1. doi:10.4172/2161-0959.S1-001

Copyright: (c) 2012 Eleftheriadis T, et al. This is an open-access article distributed under the terms of the Creative Commons Attribution License, which permits unrestricted use, distribution, and reproduction in any medium, provided the original author and source are credited. 
fetuin-A levels are downregulated, a fact which is associated with increased mortality $[25,26]$. Furthermore, low fetuin-A and high CRP levels are detected in patients with calciphylaxis [20,27].

\section{Epidemiology}

The reported rates of calciphylaxis vary among centers. In Germany, until recently, 50 cases per year were reported. However, in a study of 242 dialysis patients, calciphylaxis was present in 4\% [28].

\section{Risk Factors}

1. End stage renal disease patients. This population accounts for most cases and this is why the term "calcific uremic arteriolopathy" has been used as a synonym for calciphylaxis $[4,6]$.

2. Female sex $[4,10]$.

3. Obesity [29].

4. Hyperphosphatemia $[10,11]$

5. Vitamin D or its analogs and calcium based phosphate binders [6-9]. Possibly however, selective Vitamin D receptor activators could play a beneficial role through their non-classical effects [18]. However, any vitamin D therapy would need to be used very cautiously and with close monitoring because of the risk of increasing the Ca $\mathrm{x} P$ product.

6. Warfarin $[4,18]$

7. Corticosteroids [30] There is a study however which demonstrates a beneficial effect of corticosteroids when timely administered [6].

8. Hypercoagulability states like protein C or S deficiency or the antiphospholipid syndrome [31-33].

\section{Non-uremic Causes of Calciphylaxis}

Primary hyperpararthyroidism, malignancy (e.g. cholangiocarcinoma, malignant melanoma, multiple myeloma, chronic myelocytic leukemia and metastatic breast cancer), alcoholic liver disease, connective tissue diseases (giant cell arteritis and rheumatoid arthritis), diabetes and weight loss have been reported among others as causes of nonuremic calciphylaxis. The proposed pathogenetic mechanisms include deficiency of vascular calcification inhibitors (e.g. Fetuin-A and MGP), disturbances of NF-kB receptor activator (RANK), RANK ligand and osteoprotegerin leading to extraskeletal calcification, decrease in the activity of MGP (due to inhibition of its vitamin K dependent carboxylation), increased levels of matrix metalloproteinases etc. However, the reported causes cannot always be clearly differentiated from simple associations and the exact underlying mechanisms are far from being understood. Interestingly, systemic use of corticosteroids had detrimental effects in most cases of non-uremic calciphylaxis [22,23].

\section{Clinical Features-diagnosis}

Calciphylaxis lesions are usually found in areas rich in adipose tissue like the thighs, abdomen and buttocks $[4,6,29]$. It can however affect the fingers, with a better prognosis or other unusual places like the breast or genital area $[34,35]$. Hard painful subcutaneous violaceous nodules or plaques are the initial lesions followed by dysesthesia, the development of livedo reticularis and eschars. The subqutaneous calcified nodules and/or plaques are often palpable and pruritus may develop in adjacent areas. These lesions can be ulcerated or infected $[4,6]$. Differential diagnosis of skin lesions includes lesions due to peripheral vascular disease with distal extremity lesions, cholesterol emboli, cryoprecipitate disorders, vasculitic lesions (autoimmune disease associated, hepatitis- $\mathrm{C}$ associated or other necrotizing vasculitides), oxalate vasculopathy, calcinosis cutis and other rare skin disorders [12,36,37].

Medial calcification and intimal hyperplasia of small subcutaneous arterioles and vascular thrombosis are common histological features. Subcutaneous tissue calcification with cellulitis and lipoid necrosis, as well as inflammatory cell infiltration is not uncommon $[38,39]$. Although skin biopsy is required for a definite diagnosis, three points warrant further attention. Firstly, a biopsy must be performed with special caution since it can produce a non-healing ulceration that can accelerate the lesions and dramatically increase mortality. Secondly, needle biopsy does not provide enough tissue and a small skin incision around the main lesion is required. Furthermore, special stains should be used like AgNO3-Kossa method or Alizarin Red in order to demonstrate the calcifications $[6,40]$. Serum PTH, Ca and P levels are often but not always elevated.

Conventional x-rays, high resolution computed tomography or even better $\mathrm{x}$ ray mammography demonstrate the calcifications. In the latter method, arteriolar calcification is depicted as a plexus in the affected area. Mammography is used for imaging of lesions of the extremities and requires compression between two plaques which could be extremely painful in case of calciphylaxis [41].

Alternatively, ${ }^{99} \mathrm{Tc}$ bone scintigraphy might offer a noninvasive modality that could be used in diagnosis and disease monitoring since the tracer is accumulated in lesions where osteopontin, a bone protein is present $(42,43)$. However, its findings could be misinterpreted in the presence of severe hyperparathyroidism.

\section{Prognosis}

Calciphylaxis carries a poor prognosis. One and five year survival rates are $45 \%$ and $35 \%$ respectively [44]. Intensive wound care, treatment of infections, aggressive management of calcium and phosphorus balance and novel therapies seem to be quite promising in improving survival $[30,44]$.

\section{Management of Calciphylaxis}

Due to the fact that cases of calciphylaxis are sporadic and relatively uncommon, large prospective studies are lacking. Current management is mostly based on small retrospective studies. However, emerging therapies are promising for the future. Creation of registries and data bases for calciphylaxis will prove beneficial in the better evaluation of these therapies.

\section{Current Therapies}

Intensive wound care for prevention of local or systemic infection is mandatory. It encompasses the use of special enzymes for dead tissue removal, wound dressings and antibiotics administration if necessary [45]. Surgical debridement is usually extremely painful and increases the risk of sepsis.

Correction of the underlying plasma calcium and phosphorus abnormalities is required in order to lower the $\mathrm{Ca} \times \mathrm{P}$ product below $55 \mathrm{mg}^{2} / \mathrm{dl}^{2}$ and keep serum P levels between 3.5 and $5.5 \mathrm{mg} / \mathrm{dl}$ [46]. Diet 
restriction and non calcium based phosphate binders like sevelamer or lanthanum are necessary to achieve these goals $[8,9,47]$. Intensive dialysis (HD or PD) with a lower calcium bath can be very helpful $[8,9,48]$.

Management of hyperparathyroidism should be aggressive. Calcimimetics (cinacalcet) which, besides PTH suppression, lower Ca X $\mathrm{P}$ product may be used instead of vitamin $\mathrm{D}$ and analogs which tend to elevate Ca x P product [49,50]. In refractory cases, parathyroidectomy seems to be the only solution and could be beneficial [1-5].

Vitamin $\mathrm{K}$ inhibitors like Coumadin or warfarin must be immediately discontinued. Low molecular weight heparin can be used instead.

\section{Novel Therapies}

\section{Sodium thiosulphate}

This agent has been used for over one hundred years for the management of conditions like cyanide poisoning and nephrocalcinosis. Sodium thiosulphate has been lately involved in the treatment of calciphylaxis [51-55]. Although dosing (5-25g IV, 3-4/wk) and duration of treatment ( 6 months -2 years) vary among studies, significant relief from pain, improvement of inflammation and wound healing are reported. Sodium thiosulphate is believed to dissolve precipitated calcium from tissues to soluble calcium thiosulphate, which can be more effectively removed by hemodialysis. Furthermore, STS may promote vasodilation via the vasodilatory properties of its metabolite hydrogen sulfide and its antioxidative action (as it enhances glutathione generation). STS may also restore endothelial dysfunction due to decreased smooth muscle cell proliferation (through nitric oxide synthesis induction), its antithrombotic properties and its action on matrix metalloproteinases. STS is a rather safe agent. High anion gap metabolic acidosis due to sulphate retention in ESRD patients can be managed by raising bicarbonate concentration during the dialysis session $[12,36]$.

\section{Bisphosphonates}

They inhibit bone catabolism, macrophage activity and inflammation. In one study, six doses of intravenous pamidronate resolved the lesions in a CKD patient [56]. In another study, oral etidronate administration showed favorable results [57]. The possible underlying mechanisms may include reduction of high bone absorption and $\mathrm{Ca}$ control, anti-inflammatory properties, or direct effects on tissue calcification (increase in osteoprotegerin and inhibition of RANKL, lowering of bone alkaline phosphatase activity and inhibition of calcium-phosphate crystal formation). [12] These drugs have not been adequately tested in dialysis patients, they may increase the risk of lowering bone turnover and their use is contraindicated in cases of adynamic bone disease.

\section{Hyperbaric oxygen}

In general, wound healing is impaired if tissue oxygen partial pressure falls below $20 \mathrm{mmHg}$. Also, hypoxemia inhibits the antibacterial activity of neutrophils. Hyperbaric oxygen therapy is a way to restore adequate tissue oxygenation by delivering $100 \%$ of oxygen under high pressure with the patient in a sealed chamber [58,59]. Only one retrospective study in which, 9 patients with calciphylaxis were treated with an average of 4090 -minute sessions at 2.5 atmospheres with good results in 8 of them has been reported [59]. More studies are needed in order to justify the use of this expensive and not widely available therapy in the treatment of cacliphylaxis.

\section{Corticosteroids}

There is a study in which prednisone administration in 14 hemodialysis patients with non ulcerated lesions of calciphylaxis resulted in improvement or stabilization of 11 of them [6]. However, the use of all immunosuppressants in patients at high risk of sepsis could be very dangerous and further studies are required to establish the role of corticosteroids in calciphylaxis. Under the current knowledge they should be used with great caution only in cases where other measures have proved ineffective and should be completely avoided in nonuremic calciphylaxis.

\section{Lower extrimities revascularization procedure}

There are few reports of patients, however with disappointing results [60].

\section{Lucilia sericata larvae (common green bottle fly)}

They have been tested with success [61]. These larvae can debride wounds. They enhance fibroblast migration and secrete antibacterial substances mainly against Gram positive bacteria including methicillin and vancomycin resistant staphylococci.

To summarize, calciphylaxis is characterized by systemic medial calcification of the arterioles, i.e. calcification of intima media, vascular thrombosis leading to tissue ischemia including skin ischemia and, hence, skin necrosis. The lesions are usually located in thighs, abdomen and buttocks. It is seen almost exclusively in patients with stage 5 $\mathrm{CKD}$, however the disease is not limited to patients with kidney failure. Disturbed calcium and phosphorus homeostasis (increased $\mathrm{Ca} \times \mathrm{P}$ product), decreased calcification inhibitors and inflammation seem to be the principal factors involved in the pathogenesis of calciphylaxis. Calciphylaxis carries a poor prognosis and most patients die from sepsis. Current therapeutic management requires wound care and aggressive control of calcium and phosphorus control. Novel therapies are under testing, among which sodium thiosulphate seems to be most promising.

\section{References}

1. Arch-Ferrer JE, Beenken SW, Rue LW, Bland KI, Diethelm AG (2003) Therapy for calciphylaxis: an outcome analysis. Surgery 134: 941-944

2. Llach F, Velasquez Forero $F$ (2001) Secondary hyperparathyroidism in chronic renal failure: pathogenic and clinical aspects. Am J Kidney Dis 38: 20-33.

3. Girotto JA, Harmon JW, Ratner LE, Nicol TL, Wong L, et al. (2001) Parathyroidectomy promotes wound healing and prolongs survival in patients with calciphylaxis from secondary hyperparathyroidism. Surgery 130: 645-650.

4. Coates T, Kirkland GS, Dymock RB, Murphy BF, Brealey JK, et al. (1998) Cutaneous necrosis from calcific uremic arteriolopathy. Am J Kidney Dis 32 384-391.

5. Duffy A, Schurr M, Warner T, Chen $H(2006)$ Long-term outcomes in patients with calciphylaxis from hyperparathyroidism. Ann Surg Oncol 13: 96-102.

6. Fine A, Zacharias $\mathrm{J}$ (2002) Calciphylaxis is usually non-ulcerating: risk factors outcome and therapy. Kidney Int 61: 2210-2217.

7. Bleyer AJ, White WL, Choi MJ (2000) Calcific small vessel ischemic disease (calciphylaxis) in dialysis patients. Int J Artif Organs 23: 351-355.

8. Russell R, Brookshire MA, Zekonis M, Moe SM (2002) Distal calcific uremic 
Citation: Eleftheriadis T, Leivaditis K, Antoniadi G, Liakopoulos V (2012) Calciphylaxis: Current Management and Emerging Therapies. J Nephrol Therapeutic S1. doi:10.4172/2161-0959.S1-001

arteriolopathy in a hemodialysis patient responds to lowering of $\mathrm{Ca} \times \mathrm{P}$ product and aggressive wound care. Clin Nephrol 58: 238-243.

9. Don BR, Chin Al (2003) A strategy for the treatment of calcific uremic arteriolopathy (calciphylaxis) employing a combination of therapies. Clin Nephrol 59: 463-470.

10. Mazhar AR, Johnson RJ, Gillen D, Stivelman JC, Ryan MJ, et al. (2001) Risk factors and mortality associated with calciphylaxis in end-stage renal disease. Kidney Int 60: 324-332.

11. Block GA (2000) Prevalence and clinical consequences of elevated $\mathrm{Ca} \times \mathrm{P}$ product in hemodialysis patients. Clin Nephrol 54: 318-324.

12. Ross EA (2011) Evolution of treatment strategies for calciphylaxis. Am $J$ Nephrol 34: 460-467.

13. Hayden MR, Goldsmith DJ, Sowers JR, Khanna R (2008) Calciphylaxis: calcific uremic arteriolopathy and the emerging role of sodium thiosulphate. Int Uro Nephrol 40: 443-451

14. Murshed M, Schinke T, McKee MD, Karsenty G (2004) Extracellular matrix mineralization is regulated locally; different roles of two gla-containing proteins. J Cell Biol 165: 625-630.

15. Luo G, Ducy P, McKee MD, Pinero GJ, Loyer E, et al. (1997) Spontaneous calcification of arteries and cartilage in mice lacking matrix GLA protein. Nature 386: 78-81.

16. Price PA, Faus SA, Williamson MK (1998) Warfarin causes rapid calcification of the elastic lamellae in rat arteries and heart valves. Arterioscler Thromb Vasc Biol 18: 1400-1407.

17. Schurgers LJ, Spronk HM, Soute BA, Schiffers PM, DeMey JG, et al. (2007) Regression of warfarin-induced medial elastocalcinosis by high intake of vitamin $\mathrm{K}$ in rats. Blood 109: 2823-2831.

18. Vargemezis V, Liakopoulos V, Kriki P, Panagoutsos S, Leontsini M, et al. (2010) Pivotal role of paricalcitol in the treatment of calcific uremic arteriolopathy in the presence of a parathyroid adenoma. Am J Kidney Dis 55: 144-147.

19. Ketteler M (2005) Fetuin-A and extraosseous calcification in uremia. Curr Opin Nephrol Hypertens 14: 337-342.

20. Schafer C, Heiss A, Schwarz A, Westenfeld R, Ketteler M, et al. (2003) The serum protein alpha 2-Heremans-Schmid glycoprotein/fetuin-A is a systemically acting inhibitor of ectopic calcification. J Clin Invest 112: 357-366.

21. Lebreton JP, Joisel F, Raoult JP, Lannuzel B, Rogez JP, et al. (1979) Serum concentration of human alpha 2 HS glycoprotein during the inflammatory process: evidence that alpha $2 \mathrm{HS}$ glycoprotein is a negative acute-phase reactant. J Clin Invest 64: 1118-1129.

22. Nigwekar SU, Wolf M, Sterns RH, Hix JK (2008) Calciphylaxis from nonuremic causes: a systematic review. Clin J Am Soc Nephrol 3: 1139-1143.

23. Zechlinski JJ, Angel JR (2009) Calciphylaxis in the absence of renal disease: secondary hyperparathyroidism and systemic lupus erythematosus. J Rheumatol 36: 2370-2371.

24. Eleftheriadis T, Antoniadi G, Liakopoulos V, Kartsios C, Stefanidis I (2007) Basic Science and Dialysis: Disturbances of acquired immunity in hemodialysis patients. Semin Dial 20: 440-451.

25. Ketteler M, Bongartz $P$, Westenfeld R, Wildberger JE, Mahnken AH, et al. (2003) Association of low fetuin-A (AHSG) concentrations in serum with cardiovascular mortality in patients on dialysis: a cross-sectional study. Lancet 361: 827-833.

26. Hermans MM, Brandenburg V, Ketteler M, Kooman JP, Van der Sande FM, et al. (2007) Association of serum fetuin-A levels with mortality in dialysis patients. Kidney Int 72: 202-207.

27. Slough S, Servilla KS, Harford AM, Konstantinov KN, Harris A, et al. (2006) Association between calciphylaxis and inflammation in two patients on chronic dialysis. Adv Perit Dial 22: 171-174.

28. Angelis M, Wong LL, Myers SA, Wong LM (1997) Calciphylaxis in patients on hemodialysis: a prevalence study. Surgery 122: 1083-1089.
29. Janigan DT, Hirsch DJ, Klassen GA, MacDonald AS (2000) Calcified subcutaneous arterioles with infarcts of the subcutis and skin ("calciphylaxis") in chronic renal failure. Am J Kidney Dis 35:588-597.

30. Weenig RH, Sewell LD, Davis MD, McCarthy JT, Pittelkow MR (2007) Calciphylaxis: natural history, risk factor analysis, and outcome. J Am Acad Dermatol 56: 569-579.

31. Mehta RL, Scott G, Sloand JA, Francis CW (1990) Skin necrosis associated with acquired protein $\mathrm{C}$ deficiency in patients with renal failure and calciphylaxis. Am J Med 88: 252-257.

32. Rostaing L, el Feki S, Delisle MB, Durand-Malgouyres C, Ton-That H, et al. (1995) Calciphylaxis in a chronic hemodialysis patient with protein S deficiency Am J Nephrol 15: 524-527.

33. Wong JJ, Laumann A, Martinez M (2000) Calciphylaxis and antiphospholipid antibody syndrome. J Am Acad Dermatol 42: 849.

34. Thornton JJ, Dolph J (2008) Breast necrosis: Calciphylaxis a rare cause. Can J Plast Surg 16: 165-167.

35. Handa SP, Strzelczak D (1998) Uremic small artery disease: calciphylaxis with penis involvement. Clin Nephrol 50: 258-261.

36. Rogers NM, Teubner DJO, Coates PTH (2007) VASCULAR CALCIFICATION IN PATIENTS WITH KIDNEY DISEASE: Calcific uremic arteriolopathy: Advances in pathogenesis and treatment. Semin Dial 20: 150-157.

37. Arampatzis S, Liakopoulos V, Spanou Z, Stefanidis I (2010) Skin disorders in chronic renal failure. Hell Nephrol 22: 130-140.

38. Kent RB, 3rd, Lyerly RT (1994) Systemic calciphylaxis. South Med J 87: 278281.

39. Bazari H, Jaff MR, Mannstadt M, Yan S (2007) Case records of the Massachusetts General Hospital. Case 7-2007. A 59-year-old woman with diabetic renal disease and nonhealing skin ulcers. N Engl J Med 356: 10491057.

40. Goldsmith DJ (1997) Calcifying panniculitis or 'simple' inflammation? Biopsy is better than a bone scan. Nephrol Dial Transplant 12: 2463-2464.

41. Bleibel W, Hazar B, Herman R (2006) A case report comparing various radiological tests in the diagnosis of calcific uremic arteriolopathy. Am J Kidney Dis 48: 659-661.

42. Norris B, Vaysman V, Line BR (2005) Bone scintigraphy of calciphylaxis: syndrome of vascular calcification and skin necrosis. Clin Nucl Med 30: 725 727.

43. Soni S, Leslie WD (2008) Bone scan findings in metastatic calcification from calciphylaxis. Clin Nucl Med 33: 502-504.

44. Lal G, Nowell AG, Liao J, Sugg SL, Weigel RJ, et al. (2009) Determinants of survival in patients with calciphylaxis: a multivariate analysis. Surgery 146 1028-1034.

45. Hahler B (2001) Calciphylaxis in the patient with chronic renal failure. Dermato Nurs 13: 435-436, 449

46. Moe SM, Drüeke TB, Block GA, Cannata-Andía JB, Elder GJ, et al. (2009) KDIGO clinical practice guideline for the diagnosis, evaluation, prevention, and treatment of Chronic Kidney Disease-Mineral and Bone Disorder (CKD-MBD). Kidney Int Suppl S1-130.

47. Chan MR, Yevzlin AS, Hinshaw M, Jaffery JB (2008) Calciphylaxis responsive to lanthanum carbonate (FOSRENOL) therapy. WMJ 107: 335-338.

48. Lipsker D, Chosidow O, Martinez F, Challier E, Frances C (1997) Low-calcium dialysis in calciphylaxis. Arch Dermatol 133: 798-799.

49. Velasco N, MacGregor MS, Innes A, MacKay IG (2006) Successful treatment of calciphylaxis with cinacalcet-an alternative to parathyroidectomy? Nephro Dial Transplant 21:1999-2004.

50. Pallure V, Comte C, Leray-Mouragues H, Dereure O (2008) Cinacalcet as firstline treatment for calciphylaxis. Acta Derm Venereol 88: 62-63.

51. Yatzidis H (1985) Successful sodium thiosulphate treatment for recurrent calcium urolithiasis. Clin Nephrol 23: 63-67. 
Citation: Eleftheriadis T, Leivaditis K, Antoniadi G, Liakopoulos V (2012) Calciphylaxis: Current Management and Emerging Therapies. J Nephrol Therapeutic S1. doi:10.4172/2161-0959.S1-001

52. Cicone JS, Petronis JB, Embert CD, Spector DA (2004) Successful treatment of calciphylaxis with intravenous sodium thiosulfate. Am J Kidney Dis 43:11041108.

53. Hayden MR, Goldsmith DJ (2010) Sodium thiosulfate: new hope for the treatment of calciphylaxis. Semin Dial 23: 258-262.

54. Guerra G, Shah RC, Ross EA (2005) Rapid resolution of calciphylaxis with intravenous sodium thiosulfate and continuous venovenous haemofiltration using low calcium replacement fluid: case report. Nephrol Dial Transplant 20: 1260-1262.

55. Tindni A, Gaurav K, Panda M (2008) Non-healing painful ulcers in a patient with chronic kidney disease and role of sodium thiosulfate: a case report. Cases $\mathrm{J}$ 1: 178 .

56. Monney P, Nguyen QV, Perroud H, Descombes E (2004) Rapid improvement of calciphylaxis after intravenous pamidronate therapy in a patient with chronic renal failure. Nephrol Dial Transplant 19: 2130-2132.
57. Shiraishi N, Kitamura K, Miyoshi T, Adachi M, Kohda Y, et al. (2006) Successfu treatment of a patient with severe calcific uremic arteriolopathy (calciphylaxis) by etidronate disodium. Am J Kidney Dis 48:151-154.

58. Dean SM, Werman H (1998) Calciphylaxis: a favorable outcome with hyperbaric oxygen. Vasc Med 3: 115-120.

59. Basile C, Montanaro A, Masi M, Pati G, De Maio P, et al. (2002) Hyperbaric oxygen therapy for calcific uremic arteriolopathy: a case series. J Nephrol 15 $676-680$.

60. Friedman SG (2002) Leg revascularization in patients with calciphylaxis. Am Surg 68:591-592.

61. Tittelbach J, Graefe T, Wollina U (2001) Painful ulcers in calciphylaxis combined treatment with maggot therapy and oral pentoxyfillin. J Dermatolog Treat 12: 211-214 